\title{
Women in the Qur'an: An Emancipatory Reading
}

\author{
Asma Lamrabet \\ Translated from the French by Myriam Francois-Cerrah. \\ Square View, 2016. 172 pages.
}

Asma Lamrabet's Women in the Quran: An Emancipatory Reading sufficiently fulfills its promise to offer an emancipatory approach to the Qur'an. It argues for a re-reading of the entire Islamic tradition, not the Quran alone, in a way that embraces women's full humanity. Despite some of its less convincing arguments, its overall thesis of women's liberation through the Quran and its argument that the Qur'an is in fact anti-patriarchal are well-presented.

The book contains an Introduction and two sections. The Introduction offers a vision standing between the conservative Islamic and the western Islamophobic approaches. Unlike these two approaches, which each deem the Muslim woman voiceless, Lamrabet's method empowers Muslim women through a reclamation of their original, Quranic status.

Part One, "When the Qur'an Speaks of Women," offers alternative readings of Quranic narratives that involve women, such as Balqis, Zulaykha, Asiya the Pharaoh's wife, Maryam, Sarah, and Hagar. It also includes those women whose stories the tradition neglects, such as Moses' mother and Shu'ayb's daughter. This section illustrates the impact of a story about a woman that is actually centered on her, unlike in the traditional versions. A fascinating discussion here is about Balqis, whose honorific treatment in the Quran troubled male scholars. It was so unimaginable for them to view a woman as a revered queen that they questioned her human origin. Some concluded that she must have been of jinn ancestry; others derided the men of her kingdom for "allowing themselves to be governed" by an iljatu, a derogatory term meaning "donkey" or "disbeliever" (33). This attitude diminishes Balkis's humanity; through it, the commentators could "rest assured" that they need not take her seriously since she is only half human.

Part Two, "When the Qur'an Speaks to Women," challenges the claim that the language of the Qur'an is masculine. Lamrabet discusses the women who complained that the Qur'an does not address them (e.g., Umm Salama, Asma bint Umays, and Umm 'Umarah al-Ansariyyah). While she argues that the issue was resolved with the revelation of Q 33:35, even this verse does not directly speak to women, as the Qur'an often does with men (e.g., Q 2:221; 2:223; 4:34). Still, God's response to women's concerns and 
grievances, as in the examples of the above women and Khawla bint Tha'laba (132), speaks to the Qur'an's anti-patriarchal voice. By devoting verses to Khawla's concern about her husband's exploitation of her through zihār (Q 58:1-2), the Qur'an endorses women's moral courage to protest oppression.

Lamrabet continues her discussion by addressing four issues commonly invoked to prove Islam's misogyny: polygyny, inheritance, testimony, and permission to men to hit their wives. On polygyny, Lamrabet emphasizes that the Qur'an discourages it by requiring equal treatment of all wives while simultaneously reminding men that they can never be just to multiple wives. Ineffectively, to show that the prophetic model discouraged polygamy, Lamrabet asks, "did the Prophet not express his strong disapproval of polygamy when he learned that 'Ali, husband to his daughter Fatima Zahra, wished to marry a second wife?" (144). Since the Prophet himself had even more than the number of wives the Qur'an "limits" other Muslim men to, this is not a convincing argument.

On female testimony, Lamrabet argues that the verse on testimony $(\mathrm{Q}$ $2: 282$ ) which seemingly treats women unequally is about attestation, not testimony, and that it carries no legislative remit. While a testimony occurs in front of a judge who decides upon the veracity of the claims, attestation refers to a case between two people (145). She argues that this verse in fact advocates women's participation in spaces viewed strictly as men's, such as the management of commercial affairs. She invokes Q 24:6-8, where "the testimony of a woman is absolutely equal to that of a man"-although in this verse, the wife's testimony in fact overshadows the husband's. Moreover, in the transmission of hadith, which is also a form of testimony, women's and men's testimony is treated equally.

On inheritance, Lamrabet again calls for a context-based meaning of the verses-i.e., in seventh-century Arabia, women were not expected to inherit anything. She notes that the presumed unequal distribution refers only to the inheritance of sisters and brothers, not all women and men. In fact, there are cases where a man inherits and the woman does not, where the woman inherits and the man does not, or one inherits more than the other regardless of gender but due to their closeness of kinship to the deceased (150). Her justifications are not always convincing, however: explaining why husbands receive a higher portion because of their role as financial providers, she writes that it is "to give men a sense of responsibility because women might find themselves unable to manage the economic needs of the family due to pregnancy" (150). References to women's pregnancy as explanatory of their roles and rights are always intriguing, giv- 
en that pregnancy is not women's default position. This rule appears to be justified with exceptions treated as the norm. However, unlike most other scholars speaking on inheritance, who seldom recognize lived realities that require women to work, Lamrabet does address reality and condemns the "blind application" of Islamic principles.

The author's approach to Q 4:34 (on wife-beating) is largely unpersuasive, except her claim that daraba has been mistranslated. Her reading relies on the assumption that pre-Islamic Arab men mistreated their women to such an extent that Q 4:34's permission to discipline their wives "through a gradual process" is in fact justice towards women. Lamrabet explains that the reason the Prophet was corrected when he instructed a woman to hit her husband in retaliation is that men complained to the Prophet that their wives would all rebel against them. That is, a woman's self-defense would lead to a social revolt, and to prevent this, husbands' right as disciplinarians was protected. Lamrabet claims that scholars have "unanimously" prohibited "all violence against women" (157); this is inaccurate, as a historical exegetical study of Q 4:34 shows (see Ayesha Chaudhry's scholarship). Lamrabet argues that daraba in this verse does not mean "to hit." She notes that the term appears multiple times in the Qur'an, where its meanings include "to cover," "to go away from," "to strike," and "to accompany." She questions the scholars' choice to interpret it as "to beat" when several other meanings would have worked both contextually and in light of the Qur'an's message of compassion.

In the Conclusion, Lamrabet discusses Muslim women's interrupted revolution in the early days of Islam. While women were initially condemning the patriarchy of their time, their contributions and concerns were later subverted through various processes as was the spirit of liberation that Islam brought, normalizing misogynistic interpretations of the Qur'an.

An addendum to the book, a "Publisher's End Notes," explains-or likely mansplains-some of Lamrabet's ideas. It is unclear which points the publisher is responding to. E.g., Point F states, "No source is provided for this claim" without referencing said claim. Erroneous statements appear elsewhere, such as Point E: "In the Islamic tradition, women have never been regarded as inferior creatures." Historical scholars did in fact view women as inferiors, and Lamrabet provides many such examples (e.g., 15, 25). The publisher's notes intend to "correct" Lamrabet's assertions through patronizing and dismissive comments such as "this may be based on her experience" and "the author's discomfort appears to be based on a misunderstanding of the verses." Since the publisher's lack of research on the sub- 
ject is clear, their claims that they could not find any support for Lamrabet's statements are unreliable.

Like any valuable scholarship, the book contains flaws, of which a significant one is the lack of citation of women's scholarship. Ironically, while challenging the patriarchy of denying women's contributions to Islam, Lamrabet herself hardly cites Muslim women, although she frequently cites past and contemporary men. She is clearly familiar with Muslim women's scholarship, as she notes earlier in the book (5). Among the scholars whose works should have been engaged are Fatima Sadiqi, Olfa Youssef, and Fatima Mernissi, among others who have written extensively in Arabic and/ or French on issues that Lamrabet highlights. Also, the translator, Myriam Francois-Cerrah, uses the outdated term "mankind" for "humanity" and "man" for "humans" or "people" (e.g., 32). Finally, like apologist scholarship on women and Islam, the book offers a reductive portrayal of pre-Islamic Arab women's rights, which were purportedly non-existent and improved dramatically with the advent of Islam.

Suitable for various audiences, particularly in Islamic Studies and Women's Studies, the book is a conversation with practicing Muslimswho can appreciate its faith-based approach. The translator has done an immense service by expanding the book's audience. Lamrabet's book is also commendable for its accessibility to non-academic audiences. Moreover, mainstream Muslim scholars and preachers of Islam will benefit from the non-traditional, non-orthodox interpretations of women-centered verses of the Qur'an that have historically privileged male perspectives and interests.

Shehnaz Haqqani

Diversity Scholar Fellow Women's and Gender Studies Ithaca College 